
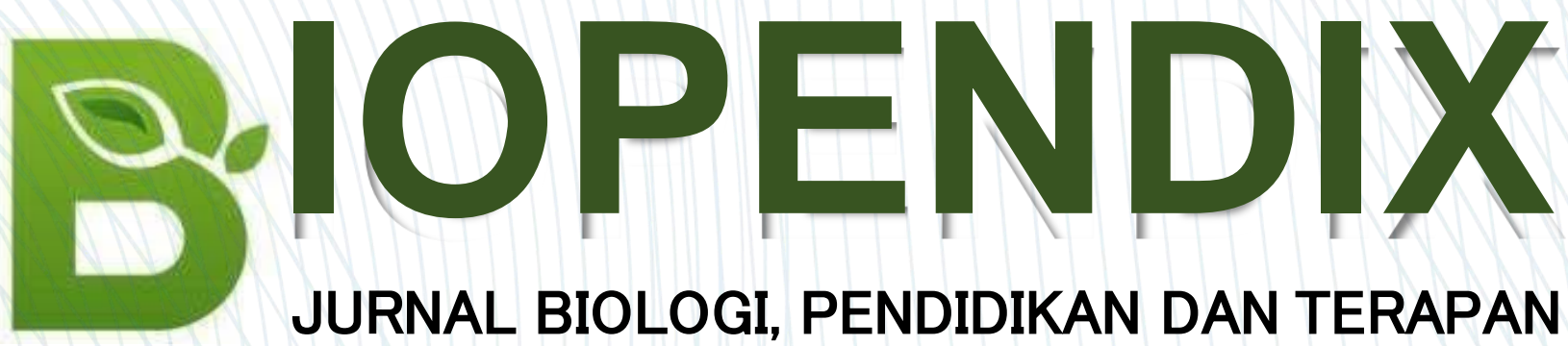

JURNAL BIOLOGI, PENDIDIKAN DAN TERAPAN

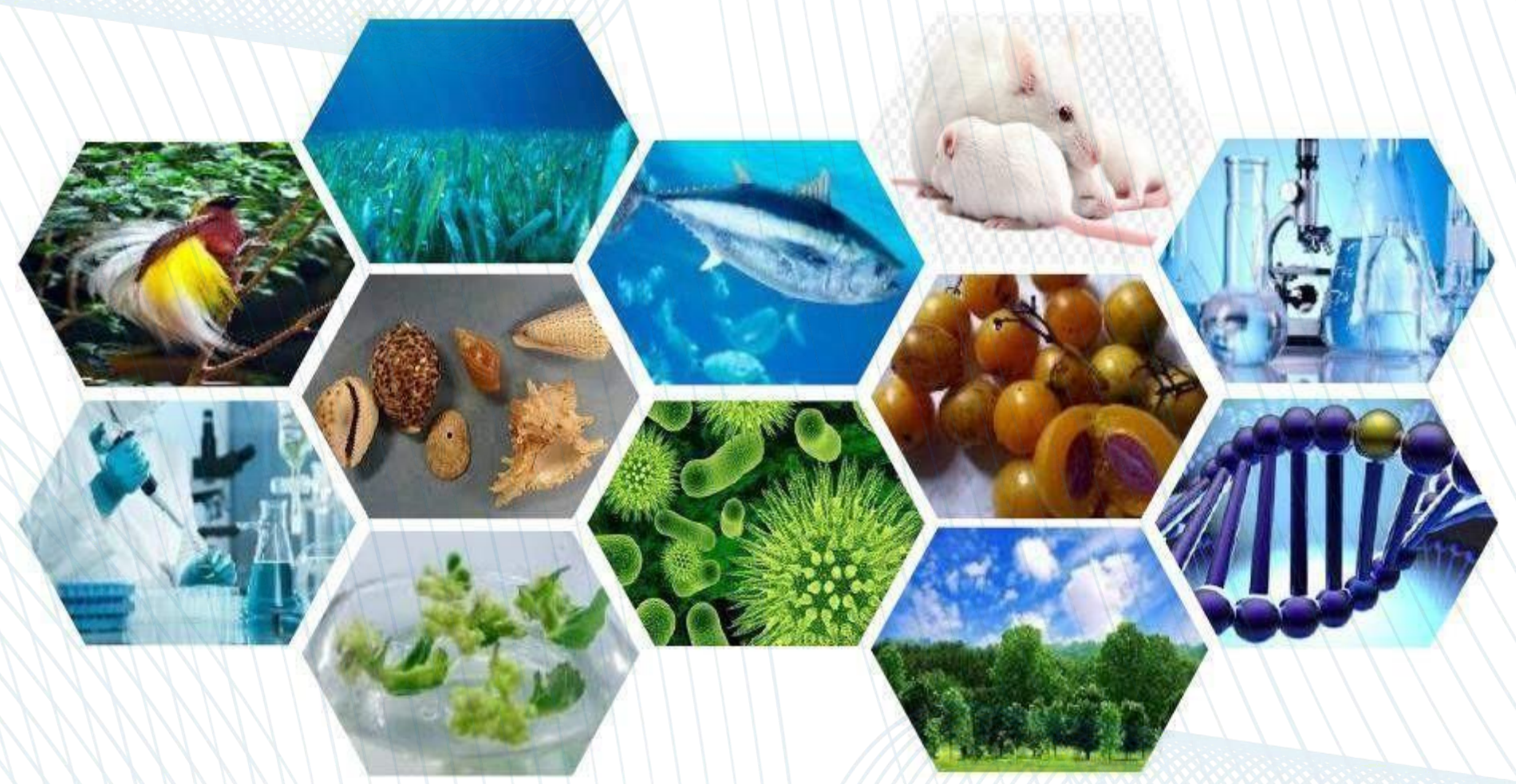

PUBLISHER BY:

BIOLOGYEDUCATION, UNPATTI AMBON - MALUKU 


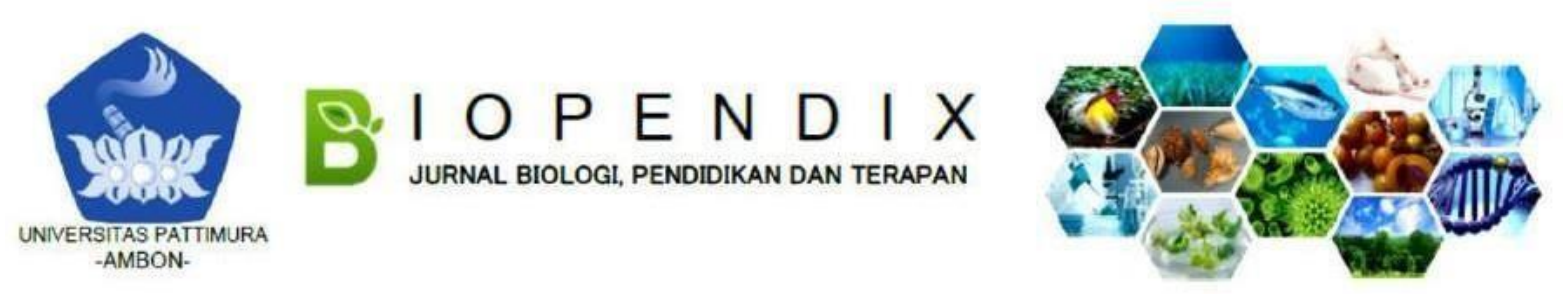

\title{
IDENTIFIKASI PENGUATAN NILAI-NILAI PENDIDIKAN KARAKTER MELALUI BERPIKIR KRITIS GURU BIOLOGI PADA SISWA KELAS XI MAN AMBON
}

\author{
Hanisu Alkarim¹, Johanis F. Rehena ${ }^{2}$, Hasan Tuaputty*2, Dominggus Rumahlatu² \\ ${ }^{1}$ Mahasiswa Program Pascasarjana Pendidikan Biologi \\ ${ }^{2}$ Dosen Program Pascasarjan Pendidikan Biologi
}

\author{
Corresponding author: Hasan Tuaputty; e-mail: hanisualkarim@gmail.com
}

\begin{abstract}
Background: The teacher holds an important role in developing and strengthening the education of students' character in a Biology learning process. The character of the teacher is one of the factors that must be developed in the curriculum. Critical thinking includes character and skills which are two things that can not be separated in a person.

Method: This research was conducted in July-August 2018, using a questionnaire distribution method of 60 students and interviews with the head of MAN, deputy head of curriculum, Biology teacher, religion teacher, BK teacher and Committee teacher.

Results: This study shows the character of Biology teachers towards class XI students including the Good category, strengthening the character education of students in the bad category, and critical thinking of Biology teachers in the good category, and the relationship of the character of the Biology teacher.

Conclusion: Strengthening the value of student character education has a strong relationship that is with a value of 0.867 .
\end{abstract}

Keywords: Biology Teacher Character Values, Strengthening Character Values of Grade XI Students, Critical Thinking of Biology Teachers.

\begin{abstract}
Abstrak
Latar Belakang: Guru memegangi peranan yang penting dalam mengembangkan dan memberikan penguatan pendidikan terhadap karakter siswa dalam suatu proses pembelajaran Biologi. Karakter guru merupakan salah satu faktor yang harus dikembangkan dalam kurikulum. Berpikir kritis meliputi karakter dan keterampilan yang merupakan dua hal yang tidak dapat terpisahkan didalam diri seseorang.

Metode: Penelitian ini dilakukan pada bulan Juli-Agustus 2018, menggunakan metode pembagian kuisioner sebanyak 60 siswa dan wawancara kepada pihak kepala MAN, wakil kepala bagian kurikulum, guru Biologi, guru agama, guru BK dan guru Komite .

Hasil: Penelitian ini menunjukan karakter guru Biologi terhadap siswa kelas XI termasuk kategori Baik, penguatan pendidikan karakter siswa kategori tidak baik, dan berpikir kritis guru Biologi kategori baik, dan hubungan karakter guru Biologi.
\end{abstract}

Kesimpulan: Penguatan nilai pendidikan karakter siswa memiliki hubungan yang kuat yaitu dengan nilai 0,867 .

Kata Kunci: Nilai Karakter Guru Biologi , Penguatan Nilai-nilai Karakter Siswa Kelas XI, Berpikir Kritis Guru Biologi. 


\section{PENDAHULUAN}

Guru memegang peranan yang penting dalam mengembangkan dan memberikan penguatan pendidikan terhadap karakter siswa dalam suatu proses pembelajaran Biologi. Guru harus memiliki karakter kecerdasan, perhatian, kesabaran, dan memberikan kreaktifitas terhadap siswa. Dengan demikian karakter guru merupakan salah satu faktor yang harus dikembangkan dalam kurikulum. Karakter guru yang baik dapat menciptakan suasana dan hubungan yang baik serta kondusif dengan siswa (Sudati, 2014).

Seorang guru dalam berinteraksi dengan siswanya harus memiliki teladan yang baik, senantiasa bersikap bijak terhadap siswa, tidak suka marah, memotifasi siswa untuk belajar, mampu merangsang siswa untuk berkreasi, tidak pilih kasih, memberikan perintah secara menyenangkan, memberikan teguran secara bijak, suka memberi ide, masukan, mengawali hubungan pedagogiknya di dalam dan di luar sekolah dengan siswa dengan bahasa cinta dan membuang jauhjauh bahasa kekerasan dan intimidasi (Sudati, 2014).

Pendidikan karakter bagi siswa sangat berguna untuk menghadapi kehidupan dimasa yang selanjutnya. Pendidikan karakter merupakan suatu kebiasaan baik yang mampu menjaga seseorang dari berbagai krisis moral yang sekarang ini sedang menggerogoti karakter siswa. Oleh karena itu, karakter guru saat ini digencarkan dari pemerintah kepada masyarakat, khususnya kepada lembaga pendidikan baik formal maupun informal. Mulai dari pra sekolah sampai di perguruan tinggi, mengarahkan pembelajaran untuk mencapai target yang diinginkan, yaitu siswa harusmemiliki karakter yang mulia (Titin, 2016).

Berpikir kritis meliputi karakter dan keterampilan yang merupakan dua hal yang tidak dapat terpisahkan didalam diri seseorang. Dilihat dari perspektif psikologi perkembangan, karakter dan keterampilan harus saling menguatkan, karena itu keduanya harus secara eksplisit di ajarkan bersama-sama. Karakter tampak dalam diri seseorang sebagai pemberani, penakut, pantang menyerah, mudah putus asa, dan lain sebagainya. Suatu karakter manusia merupakan motifasi internal yang konsisten dalam diri seseorang dalam bertindak, merespon seseorang, peristiwa, atau situasi biasa. Berbagai pengalaman yang didapat memperkuat teori karakter manusia yang ditandai sebagai kecenderungan yang tampak (Septi, 2015).

\section{METODE}

Adapun tipe penelitian ini bersifat deskriptif yaitu menggambarkan fenomena karakter guru, menggambarkan besarnya masalah yang diteliti, dan fenomenafenomena kegiatan guru dan siswa, dan fenomena kegiatan pembelajaran berpikir kritis guru biologi di Madrasah Aliyah Negeri Ambon. Penelitian ini akan dilaksanakan pada tanggal 26 Juli- 28 Agustus dan pelaksanaannya bertempat di Madrasah Alyah Negeri Ambon di kota Ambon Provinsi Maluku. Yang menjadi populasi penelitian ini adalah seluruh guru dan siswa di MAN Ambon yang terlibat langsung dalam proses pembelajaran Biologi. Adapun sampel dalam penelitian ini di ambil secara purposive sampling yaitu 1 kepala sekolah, 1 guru wakil kepala sekolah bidang kurikulum, 1 guru Biologi, 1 guru Bimbingan Konseling, 1 guru komite dan 60 orang siswa yaitu siswa kelas XI IPA untuk menjadi responden. Jumlah keseluruhan sampel dalam penelitian ini adalah 65 orang sebagai responden. variabel yang digunakan dalam penelitian ini adalah (1) Variabel bebas $\left(X_{1}\right)$ yaitu karakter guru pendidikan Biologi di MAN Ambon (2) Variabel bebas $\left(X_{2}\right)$ yaitu penguatan pendidikan karakter siswa kelas XI di MAN Ambon (3) Variabel terikat ( $Y$ ) yaitu berpikir kritis guru Biologi di MAN Ambon. Analisis data yang digunakan dalam penelitian ini adalah untuk mencari dan menyusun data yang diperoleh secara sistematis dari hasil wawancara, kuesioner, catatan lapangan, dan bahan-bahan lain sehingga dapat mudah dipahami, dan temuannya dapat di informasikan pada orang lain. Untuk 
keperluan analisis data, peneliti menggunakan jenis penelitian analisis deskriptif, yaitu penelitian yang bermaksud untuk menganalisis menggunakan analisis korelasi dengan taraf signifikan $r$ 5\% dan $r 1$ $\%$ dengan bantuan program SPSS 20.0 untuk memahami fenomena tentang apa yang dialami oleh subjek penelitian yakni hubungan karakter guru, penguatan pendidikan karakter siswa dan berpikir kritis guru Biologi di MAN Ambon (Hartono, 2015).

\section{HASIL DAN PEMBAHASAN \\ Karakter Guru Biologi di MAN Ambon}

Tugas guru adalah menyampaikan materi kepada siswa dengan menggunakan cara- cara tertentu dalam proses pembelajaran yang dilaksanakan.

Keberhasilan guru dalam menyampaikan materi kepada peserta didiknya, tergantung pada diri guru itu sendiri. Seorang guru Biologi harus mampu membangun sebuah hubungan dengan seluruh siswa dan menggunakan hubungan yang terjalin sebagai sebuah kesempatan untuk memberikan didikan moral. Interaksi yang terjalin antara guru dan setiap siswa sangatlah pentingnya untuk di kembangkan. Kepala sekolah di MAN Ambonjuga sangat mendukung peran para guru dalam memberikan perhatian kepada para siswanya. Kesadaran akan pentingnya hubungan guru dan siswa ini menuntut seorang guru untuk memiliki visi moral sebagai pendidik yang baik sehingga diperlukan pandangan yang signifikan tentang moral dari interaksi- interaksi, pengalaman-pengalaman, serta harus membayangkan efek-efek jangka panjang dari pengalaman siswa di MAN terkait nilainilai kehidupan dan karakter siswa, serta teladan guru yang akan mereka terapkan dalam membantu mereka untuk berkarya dan untuk melihat pengajaran sebagai hal yang pertama kali terlihat sebagai sebuah panggilan khusus, yaitu sebagai hadiah moral dikemudian hari.

\section{Penguatan Nilai Pendidikan Karakter Siswa Kelas XI di MAN}

Madrasah Alyah Negeri Ambon merupakan salah satu lembaga pendidikan yang berciri khas beragam Islam yang berfungsi untuk mencetak atau menyiapkan peserta didik yang berkarakter baik, cerdas, terampil, dan mandiri. Berkembangnya peserta didik agar menjadi siswa yang cerdas, bertakwa kepada Tuhan Yang Maha Esa, berakhlak mulia, sehat, berilmu, cakap, kreaktif, mandiri, dan menjadi pengembang keterampilan kepada masyarakat melalui pengajaran Biologi.

Pembelajaran biologi yang di ajarkan guru mengarahkan siswa untuk melakukan perubahan perilaku dan pribadi siswa yang optimal. Perubahan tersebut ditampilkan dalam karakter siswa, sebagai perilaku yang dilandasi nilai-nilai kehidupan yang sangat luhur. Guru Biologi harus mampu mengelola kelas dalam rangkaian penyelenggaraan proses belajar mengajar di kelas sehingga guru Biologi memiliki kesempatan yang leluasa untuk mengembangkan karakter pribadi para siswa

Penguatan pendidikan kelas juga dapat di jadikan sebagai penguatan berbasis budaya sekolah, yaitu menjelaskan berbagai macam bentuk pembiasaan, model tata kelola termasuk di dalamnya pengembangan peraturan dan regulasi yang mendukung penguatan pendidikan karakter siswa. Proses pembudayaan melalui sekolah MAN dalam pengembangan penguatan pendidikan karakter yaitu dapat mengembangkan nilainilai luhur kepada siswa sehingga dapat merubah perilaku siswa menjadi yang lebih baik.

\section{Berpikir Kritis Guru Biologi di MAN Ambon}

Guru Biologi adalah salah satu guru yang menguasi bidang mata pelajaran Biologi, dan harus mampu berpikir kritis serta dapat mengembangkan materi pelajaran Biologi sesuai bidangnya. Berpikir kritis mengandung aktifitas mental dalam hal memecahkan masalah, menganalisis asumsi, memberi rasional, mengevaluasi pembelajaran, melakukan penyelidikan, dan mampu mengambil keputusan. Dalam proses pengambilan keputusan, 
kemampuan mencari, menganalisis dan mengevaluasi informasi sangatlah penting. Ciri guru yang berpikir kritis adalah ia akan selalu mencari dan memaparkan hubungan antara masalah yang didiskusikan dengan masalah atau pengalaman lain yang relevan.

Kemampuan dalam berpikir kritis akan memberikan arahan yang lebih tepat dalam berpikir, bekerja, membantu serta harus lebih akurat dalam menentukan keterkaitan sesuatu dengan lainnya. Oleh sebab itu, kemampuan berpikir kritis sangat diperlukan dalam pemecahan masalah atau dalam pencarian solusi. Pengembangan kemampuan, seperti pengamatan, analisis, penalaran, penilaian, pengambilan keputusan, dan persuasi. Semakin baik pengembangan kemampuan ini maka semakin baik pula dalam mengatasi masalah-masalah.

Kemampuan berpikir kritis baik oleh guru maupun siswa sangat perlu untuk dikembangkan demi keberhasilan mereka dalam pendidikan dan dalam kehidupan bermasyarakat. Keterampilan berpikir kritis dapat dikembangkan atau diperkuat melalui proses pembelajaran. Artinya, disamping pembelajaran mengembangkan kemampuan kognitif untuk suatu mata pelajaran tertentu.

Pembelajaran

mengembangkan keterampilan berpikir kritis. Tidak semua proses pembelajaran secara otomatis akan mengembangkan keterampilan berpikir kritis, hanya proses pembelajaran yang menggunakan modelmodel pembelajaran tertentu seperti diskusi dan pemecahan masalah yang banyak memberikan kesempatan bagi para siswa untuk berpendapat, menggunakan gagasan-gagasan dalam tulisan, mendorong kerja sama dalam mengkaji dan menemukan pengetahuan, mengembangkan tanggung jawab, refleksi diri, dan kesadaran sosial politik yang akan mengembangkan berpikir kritis. Disamping itu juga, antusiasme dari guru sangat mempengaruhi keterampilan siswa.

Guru biologi di MAN Ambon diwajibkan untuk berpikir kritis sehingga dapat membantu siswa dalam meningkatkan pemahaman materi yang dipelajari dengan mengevaluasi secara kritis argumen pada materi yang di ajarkan dengan bentuk argumentasi guru dalam kegiatan pembelajaran. Jadi berpikir kritis dalam pendidikan MAN merupakan kompetensi yang harus dicapai serta sebagai alat yang diperlukan dalam mengkontruksi pengetahuan. Berpikir yang ditampilkan dalam berpikir kritis sangat tertib dan sistematis.

Adapun data interval dalam penelitian karakter guru Biologi, penguatan nilai-nilai pendidikan karakter siswa di MAN dan berpikir kritis guru Biologi di MAN Ambon untuk mengetahui tingkat persentase, kemampuan rata-rata dan interval yang diperoleh dan kemampuan kriteria yang diperoleh berdasarkan data yang ada dapat di lihat pada tabel berikut ini.

\section{Tabel 1. Data Interval dan Persentase Karakter Guru Biologi, penguatan Nilai karakter siswa dan Berpikir Kritis Guru biologi di MAN Ambon.}

\begin{tabular}{cccc}
\hline No & Penelitian & (\%) & $\begin{array}{c}\text { Kemampuan } \\
\text { Kriteria }\end{array}$ \\
\hline 1 & $\begin{array}{c}\text { Karakter } \\
\text { guru }\end{array}$ & $62,47 \%$ & Baik \\
\hline 2 & $\begin{array}{c}\text { Penguatan } \\
\text { karakter } \\
\text { siswa }\end{array}$ & $59,28 \%$ & Tidak Baik \\
\hline 3 & $\begin{array}{c}\text { Berpikir } \\
\text { guru }\end{array}$ & $63,94 \%$ & Baik \\
\hline
\end{tabular}

Hubungan Karakter Guru Pendidikan Biologi, Penguatan Pendidikan Karakter Siswa Dengan Berpikir Kritis Guru Biologi di MAN Ambon

Berdasarkan hasil yang diperoleh di atas menunjukkan bahwa koefisien korelasi simultan adalah 0,867 . Nilai ini menunjukan bahwa hubungan antara variabel tingkat karakter guru Biologi dan penguatan nilai pendidikan karakter siswa kelas XI dengan berpikir kritis guru Biologi di MAN memiliki hubungan yang kuat. Selain itu dapat diperoleh informasi berupa koefisien determinasi sebesar $(0,752) \times 100 \%=$ $75,2 \%$ ), hal ini menunjukan bahwa kontribusi semua variabel terikat secara simultan adalah sebesar $75,2 \%$ sementara sisanya sebesar $24,8 \%$ dipengaruhi oleh faktor lain. Berdasarkan hasil yang diperoleh dapat dimaknai bahwa $\mathrm{H}_{0}$ ditolak dan $\mathrm{H}_{\mathrm{a}}$ diterima. 
Tabel 2. Hasil Uji Hipotesis Hubungan Karakter Guru Biologi, Penguatan Nilai Pendidikan Karakter Siswa kelas XI dengan Berpikir Kritis Guru Biologi MAN Ambon.

\begin{tabular}{|c|c|c|c|c|c|c|c|c|c|}
\hline \multicolumn{10}{|c|}{ Model Summary } \\
\hline \multirow[b]{2}{*}{ Model } & \multirow[b]{2}{*}{$\mathrm{R}$} & \multirow[b]{2}{*}{ R Square } & \multirow[b]{2}{*}{$\begin{array}{l}\text { Adjusted R } \\
\text { Square }\end{array}$} & \multirow[b]{2}{*}{$\begin{array}{c}\text { Std. Error of the } \\
\text { Estimate }\end{array}$} & \multicolumn{5}{|c|}{ Change Statistics } \\
\hline & & & & & $\begin{array}{l}\text { R Square } \\
\text { Change }\end{array}$ & F Change & df1 & df2 & $\begin{array}{l}\text { Sig. F } \\
\text { Change }\end{array}$ \\
\hline 1 &, $867^{\mathrm{a}}$ &, 752 & ,744 & 4,22246 & ,752 & 86,616 & 2 & 57 &, 000 \\
\hline
\end{tabular}

Keterangan: Predictors (Constant), Karakter Guru Biologi, Nilai Karakter Siswa

\section{KESIMPULAN}

Berdasarkan hasil penelitian tersebut maka dapat dikatakan bahwa karakter guru Biologi di MAN Ambon termasuk kategori baik, serta penguatan pendidikan karakter siswa termasuk kategori tidak baik dan berpikir kritis guru biologi termasuk kategori baik. Dan dilihat dari hubungan karakter guru Biologi, penguatan pendidikan karakter siswa kelas XI dan berpikir kritis guru Biologi termasuk hubungan yang kuat dengan nilai 0,867 .

\section{DAFTAR PUSTAKA}

Agil Lepiyanto. 2015. Membangun Karakter Siswa Dalam Pembelajaran Biologi. Fkip Pendidikan Biologi Universitas Muhammadyah Metro.

Agung W Dkk. 2009. Keterampilan Berpikir Kritis Siswa Dalam Pembelajaran Biologi Menggunakan Media Koran. Jurnal Pendidikan Matematika Dan Sains.

Andrianto, Tuhana Tufiq. 2011. Mengembangkan Karakter Sukses Anak Di Era Cyber. Yogyakarta: ArRuzz Media.

Arifin, Zaenal. 2015. Evaluasi Pembelajaran. Bandung: Remaja Rosdokarya.

Aris Fajar P, M.Or. 2016. Pengembangan Karakter Siswa Melalui Pembelajaran Outdor Education Pendidikan. FIK Uny: Yogyakarta.

Champbell, 2008. Biologi, Edisi Kedelapan Jilid I, Jakarta. PT Erlangga.

Dian Aswita. 2015. Identifikasi Masalah Yang Dihadapi Guru Biologi Dalam Pelaksanaan Pembelajaran Pada Materi Ekosistem. ISSN: 2337-9812. Vol.3 No. 1.

Efrems Hendro Loe Loko. 2016. Evaluasi Implementasi Kurikulum 2013 Di Tingkat Sekolah Menengah Atas
(SMA) di Kabupaten Belu, Nusa Tenggara Timur. Thesis, Fakultas Ekonomi Universitas Sanata Dharma Yogyakarta.

Hartono. 2015. Analisis Item Instrrumen. Riau: Zanava.

Huriah Rachmah. 2013. Nilai-Nilai Dalam Pendidikan Karakter Bangsa Yang Berdasarkan Pancasila Dan UUD 1945. STKIP Pasundan Cimahi, Vol. 1, No. 1.

Liliasari Dkk. 2014. Kreaktifitas Guru Biologi Dalam Memetakan Komoditas Hayati Unggulan Lokal Kedalam Pembelajaran Biologi SMA, Universitas Pendidikan Indonesia, ITB. Vol. 4, No. 1.

Mahmud. 2014. Pendidikan Karakter Konsep Dan Implikasi, Bandung: PT. Alfabeta.

Matta, Muhammad Anis. 2003. Membentuk Karakter Islam. Jakarta: Al-I'tishom Cahaya Umat.

Mayang Puspita A. 2015. Identifikasi Kesulitan Guru IPA Dalam Melaksanakan Pembelajaran Kurikulum 2013 Di SMP N. 1 Monogiri Tahun Pelajaran 2014/2015. Program Studi Pendidikan Biologi, Fakultas Keguruan Dan IImu Pendidikan. Universitas Muhamadiyah Surakarta.

Megawangi, Ratna. 2004. Pendidikan Karakter Solusi Yang Tepat Untuk Membangun Bangsa. Jakarta: Indonesia Heritage Foundation.

Meleong. 2010. Metodologi Penelitian Kualitatif. Bandung: Remaja Rosdakarya.

Miftah. 2013. Pengembangan Karakter Anak Melalui Pembelajaran IImu Sosial. BPMP Pustekkom Kemdikbud. Vol. 3 No. 2.

Miles, Matthew. B \&Michael Huberman. 2009. Analisis Data Kualitatif, Jakarta: UI- Press. 
Milya Sari. 2013. Problematika Pembelajaran Sains Di Tinjau Dari Aspek Guru. Dosen Fakultas Tarbiyah Dan Keguruan lain Imam Bondjol Padang. Vol. 1 No 4.

Nasrullah. 2015. Pembentukan Karakter Siswa Melalui Pendidikan Agama Islam. Universitas Muhammadiah Malang. Vol. 18 No 1.

Nestiti M. 2016. Implementasi Kurikulum 2013 (Kesiapan Pendidik Dan Tenaga Kependidikan Di Man Monokromo Bantul). Sunan Kalijaga, Yogyakarta.

Nurani Nisa Dkk. 2017. Proses Belajar Siswa Dalam Meningkatkan Kemampuan Berpikir Kritis Siswa. Jurnal Pendidikan. EIISN: 2502-471x. Vol. 2 No. 1.

Nursyamsi, 2014. Membentuk Karakter Peserta Didik Melalui Proses Pembelajaran Oleh Guru Kelas di Mi SD. Vol. 4 Edisi I.

Pratiwi Pujiastuti. 2013. Membangun Karakter Siswa Sekolah Dasar Melalui Pembelajaran Sains. Fip Uny. Yogyakarta.

Saidil Mursali. 2015. Mengembangkan Perilaku Berkarakter Siswa Melalui Pembelajaran Biologi Berbasis Metakognitif. Program Studi Pendidikan Biologi FMIPA IKIP Mataram.

Setyaningrum Yanur Dkk. 2011. Optimalisasi Penerapan Pendidikan Karakter Di Sekolah Menengah Berbasis Keterampilan Proses: Sebuah Perspektif Guru IPA-Biologi. Pendidikan Biologi FKIP Universitas Muhammadiyah Malang. Vol. 1. No. 1.

Sinta Dkk. 2015. Hambatan Guru Biologi Pada Pelaksanaan Kurikulum 2013 Di SMK Negeri 5 Jember. Program Studi Pendidikan Biologi, Fakultas Keguruan Dan IImu Pendidikan Universitas Muhamadiyah Jember.

Sry Haryati. 2016. Pendidikan Karakter Dalam Kurikulum 2013. FKIP UTM.

Sudati W. 2014. Pengaruh Perhatian Guru, Motivasi Belajar, Dan Kecerdasan
Emosional Terhadap Prestasi Belajar Biologi Siswa SMA Negeri 2 Bantul. Bioedukatika Vol.2. No. 1. 2014.

Suyanto \& Asep Jihad. 2013. Menjadi Guru Professional. Jakarta: Erlangga.

Suyatno. 2010. Peran Pendidikan Sebagai Modal Utama Membangun Karakter Bangsa. Pengembangan Pendidikan Budaya Dan Karakter Bangsa Oleh Kopertis Wilayah 3 DKI Jakarta, 12 Januari 2010".

Thomas Lickona. 2013. Mendidik Untuk Membentuk Karakter. Jakarta. Bumi Aksara.

Titin Dkk. 2016. Membangun Karakter Anak Usia Dini Melalui Pembelajaran Match Character: Fakultas IImu Pendidikan. Universitas Trunojoyo Madura. Issn 2089-3833. Vol. 5 No. 2.

Unujianto, B. 2009. Pembelajaran Sains Untuk Membentuk Karakter: Cyber News Edisi 29 November 2009.

Wina Sanjaya. 2008. Kurikulum Dan Pembelajaran (Teori Dan Praktik Pengembangan Kurikulum Tingkat Satuan Pendidikan (Ktsp), Kencana Jakarta.

Wiyono, B.B. 2009. Penelitian Tindakan Kelas Dan Penulisan Karya IImiah. Cetakan 1. Malang: Universitas Negeri Malang.

Yanur. Dkk. 2011. Optimalisasi Penerapan Pendidikan Karakter Di Sekolah Menengah Berbasis Keterampilan Proses: Sebuah Perspektif Guru IPABiologi. Pendidikan Biologi. Universitas Muhamadyah Malang.

Yustian Septy Dkk. 2015. Peningkatan Kemampuan Berpikir Kritis Dengan Pembelajaran Berbasis Scientific Approach Siswa Kelas X Sma Panjura Malang: Jurnal Pendidikan Biologi Indonesia, ISSN: 2442-3750.

Zainal Aqib. 2017. Pedoman Pendidikan Budaya Dan Karakter Bangsa. Yogyakarta: PT. Gava Media.

Zubaedi. 2017. Strategi Taktis Pendidikan Karakter, Depok, Rajawali Press. 